\title{
Postfire erosional processes in the Pacific Northwest and Rocky Mountain regions
}

\author{
Steven M. Wondzell ${ }^{\mathrm{a},}$, John G. King ${ }^{\mathrm{b}}$ \\ ${ }^{a}$ Pacific Northwest Research Station, Olympia Forestry Sciences Laboratory 3625 93rd Ave., S.W., Olympia, WA 98512, USA \\ ${ }^{\mathrm{b}}$ Rocky Mountain Research Station, Boise Forestry Sciences Laboratory, 316 E. Myrtle, Boise, ID 83702, USA
}

\begin{abstract}
The objective of this paper is to provide a general overview of the influence of wildland fires on the erosional processes common to the forested landscapes of the western United States. Wildfire can accelerate erosion rates because vegetation is an important factor controlling erosion. There can be great local and regional differences, however, in the relative importance of different erosional processes because of differences in prevailing climate, geology and topography; because of differences in the degree to which vegetation regulates erosional processes; and because of differences in the types of fire regimes that disrupt vegetative cover. Surface erosion, caused by overland flow, is a dominant response to wildfire in the Interior Northwest and Northern Rocky Mountains (Interior Region). A comparison of measured postfire infiltration rates and long-term records of precipitation intensity suggest that surface runoff from infiltration-excess overland flow should also occur in the Coastal and Cascade Mountains of the Pacific Northwest after fires, but this has not been documented in the literature. Debris slides and debris flows occur more frequently after wildfire in the Interior Region and in the Coastal and Cascade Mountains of the Pacific Northwest (Pacific Northwest Region). Debris flows can be initiated from either surface runoff or from soil-saturation-caused debris slides. In the Pacific Northwest Region, debris flows are typically initiated as debris slides, caused by soil saturation and loss of soil cohesion as roots decay following fire. In the Interior Region, both overland-flow-caused and debris-slide-caused debris flows occur after wildfire. Surface erosion, debris slides, and debris flows all occur during intense storms. Thus, their probability of occurrence depends upon the probability of intense storms occurring during a window of increased susceptibility to surface erosion and mass wasting following intense wildfire.

Published by Elsevier Science B.V.
\end{abstract}

Keywords: Erosion; Fire; Sediment; Overland flow; Debris slides; Debris flows; Ravel

\section{Introduction}

The objective of this paper is to provide a general overview of the influence of wildland fires on the erosional processes common to the forested landscapes of the western United States. We build upon

\footnotetext{
* Corresponding author. Tel.: +1-360-753-7691; fax: +1-360-956-2346.

E-mail address: swondzell@fs.fed.us (S.M. Wondzell).
}

several recent reviews of the effects of fire on hydrology, geomorphic processes and aquatic ecosystems (Swanson, 1981; Beschta, 1990; McNabb and Swanson, 1990; Gresswell, 1999; Wondzell, 2001). We examine the physical mechanisms driving erosion, sediment transport and deposition, and examine the effects of fire on these erosional processes. We illustrate typical erosional processes, and the influence of fire on those processes, by comparing and contrasting the Coastal and Cascade Mountains of the Pacific 
Northwest (Pacific Northwest Region) with the forested regions of the Interior Northwest and the Northern Rocky Mountains (Interior Region). Our review and synthesis of the published literature is intended to introduce geomorphologic concepts to those in other fields, and to stand as an introduction to other papers in this issue. In depth examination of specific erosional processes is available from the literature cited in this paper, and from other papers in this volume (see Benda, this issue; Meyer and Pierce, this issue; Miller et al., this issue).

\section{Erosion, transport and depositional processes}

Erosional processes occur along a continuum from the weathering of bedrock, through the movement of particles by the force of gravity (mass wasting) or movement caused by a transporting agent such as water or wind (surface erosion), to the eventual deposition of particles in ocean basins. Wind erosion is uncommon in most forested areas, so we focus on types of surface erosion resulting from overland flow of water, which includes uniformly distributed sheet erosion, rill and inter-rill erosion, and gully erosion on hillslopes, and both channel incision and bank-cutting in stream channels. We also focus on hillslope mass-wasting processes, including ravel, soil creep, deep-seated earth flows, debris slides, and debris flows.

\subsection{Surface erosion}

Because surface erosion usually requires overland flow of water, its occurrence is dependent upon the factors that control runoff generation, namely, soils, vegetation, and water input (precipitation or snowmelt). Two mechanisms can generate overland flow: (1) saturation of the soil to the surface, and (2) water input rates exceeding infiltration rates. The role of saturation-excess overland flow in erosional processes appears to be little studied. In contrast, infiltrationexcess overland flow (or Hortonian flow) has been well studied. It is the dominant mechanism driving erosion in arid and semi-arid regions, but is relatively uncommon under wetter climatic regimes. The dense overstory and understory vegetation found in most forests, combined with well developed litter layers, protect the soil surface from rain splash. Also, the litter layer can store substantial amounts of water and thereby regulate the rate at which infiltrating rainwater reaches the mineral soil surface (Martin and Moody, 2001). Further, many forest soils are well structured which also promotes rapid infiltration. Thus, infiltration-excess overland flow is rare from undisturbed forest soils, and is usually confined to local areas (Harr, 1979; Troendle and Leaf, 1980).

There is great variation in forest types from the coastal Pacific Northwest through the mountains of the Interior Columbia Basin, to the Northern Rocky Mountains. In general, differences in forest type reflect differences in climate. Maritime climates in the Pacific Northwest tend to be wetter than interior climates and are dominated by rain and rain-on-snow precipitation regimes. The Interior Region is snowmelt dominated, but also receives intense summer thunderstorms. Throughout both regions, precipitation increases with elevation. In the wet maritime climates of the Pacific Northwest Region, however, precipitation is sufficient to support dense forested vegetation from sea level to the high-elevation tree line. In the Interior Region, elevational differences in temperature, precipitation, and evapotranspiration create steep gradients in plant-available moisture that result in striking differences in forest cover. Forests tend to be restricted to wetter mountainous areas, and in many places, mountain foothills and even lower elevation mountain ranges may be too dry to support forests. At the lower elevational limit of forests, especially on south-facing hillslopes, trees are often widely spaced, total vegetative cover can be low, and litter layers may be poorly developed. Under these conditions, infiltration-excess overland flow may occur regularly (Wilcox et al., 1997). Coastal rainforests of the Pacific Northwest represent the other extreme, where annual precipitation can exceed $300 \mathrm{~cm}$ but overland flow is generally not observed from undisturbed forest soils.

Many studies have documented dramatic increases in surface erosion following wildfire (Helvey, 1980; Meyer and Wells, 1997; Robichaud and Brown, 1999; Cannon et al., 2001; Meyer et al., 2001; Moody and Martin, 2001a). Numerous factors can account for accelerated surface erosion, and the exact blend of mechanisms contributing to increased erosion changes among locations and with the sequence of postfire meteorological events. The primary factors are the availability of readily erodible sediment and changes 
in soil-infiltration rates. Easily erodible sediment is exposed to surface erosion when fire removes groundcovering vegetation, litter and organic layers that previously protected it from detachment (Johansen et al., 2001). Loss of soil structure from intense heating, combustion of soil organic matter, and soil drying can lead to decreased cohesiveness of surface soil aggregates, which are then more readily eroded. Additionally, burning of logs or other organic obstructions on hillslopes can liberate previously stored sediment to surface erosion. Finally, physical disturbances of the soil, such as wind-throw or disturbance by animal activity (Swanson, 1981) all contribute to increasing the amount of sediment available to be eroded.

Overland flow can physically detach and transport sediment and is the dominant mechanism of surface erosion after wildfire. The immediate causal factors most changed by wildfire are the soil, litter, and vegetative properties that determine infiltration rates. Ground-cover vegetation, litter, and soil organic horizons all protect the mineral soil from rain-drop impacts that can dislodge soil particles, mobilizing sediment to be eroded. Rain splash can also disrupt and possibly even compact the soil (Meyer and Wells, 1997); fine sediment dislodged by rain splash can clog soil pores causing surface sealing (Swanson, 1981; Wells et al., 1979; Martin and Moody, 2001). Surface sealing is further accentuated immediately after wildfire when organic matter binding soil aggregates has been combusted, so that aggregates easily disintegrate with physical disturbance, and when ash on the soil surface provides an abundance of fines (Swanson, 1981; Meyer and Wells, 1997; Cannon et al., 2001). Finally, heating soil organic matter can form hydrophobic compounds that coat soil particles and create a water-repellent layer. Some studies have shown that formation of hydrophobic compounds may be dependent on the type of vegetation, the antecedent soilmoisture content, and soil texture (Wells et al., 1979; McNabb and Swanson, 1990; DeBano et al., 1998; Robichaud and Hungerford, 2000; Huffman et al., 2001). In all cases, however, the formation of hydrophobic compounds depends on the soil temperature attained during a fire. Thus, the presence of a waterrepellent layer, and its depth in the soil profile is largely determined by fire behavior, fire severity and soil temperature gradients during a fire (DeBano, 2000; Robichaud and Hungerford, 2000).
Reduced rates of infiltration are usually observed after severe fires (Fig. 1) in both the Pacific Northwest Region (Swanson, 1981; McNabb et al., 1989; Johnson and Beschta, 1980), the Interior Region (Robichaud, 2000), and in other regions (Johansen et al., 2001; Martin and Moody, 2001; Wohlgemuth et al., 2001; Benavides-Solorio and MacDonald, 2001). However, the relative importance of the different physical mechanisms potentially reducing infiltration rates is not known. Further, their relative importance probably varies in time and place, with fire intensity and duration, and with time since the last fire. What is clear is that reduced infiltration after severe wildfire can contribute to increased overland flow and accelerated erosion (Elliott and Parker, 2001).

Reductions in infiltration rates reduce the threshold precipitation intensity at which overland flow occurs. In recently burned forests, precipitation intensities with recurrence intervals of 5 years or less can exceed infiltration rates, whereas precipitation intense enough to exceed infiltration rates in unburned forested areas reoccurs approximately once every 30 years (Fig. 1). Although accelerated erosion from overland flow on burned slopes is well documented for the Interior Region and other areas dominated by continental climates (Megahan et al., 1995; Meyer and Wells, 1997; Cannon et al., 2001; Martin and Moody, 2001; Meyer et al., 2001; Moody, 2001; Moody and Martin, 2001a) it has not been documented from burned-forest areas in the maritime climate-dominated Pacific Northwest Region.

The regional differences in the occurrence of infiltration-excess overland flow are typically attributed to climatic differences. Summer rainfall in the continental climate-dominated areas of the Interior Region primarily results from thunderstorms. These storms occasionally generate intense rainfall, driving infiltration-excess overland flow, especially from burned areas where infiltration rates are reduced. In contrast, many authors have suggested that the maritime climates of the Pacific Northwest Region are characterized by long-duration, low-intensity rainfall, so that infiltration rates are seldom exceeded, even after intense wildfires (Swanson, 1981; Beschta, 1990; Wondzell, 2001). This is not supported by our analysis of regional differences in rainfall intensity (Fig. 1). Rainfall intensities in excess of expected infiltration rates appear more common in the maritime climate of 


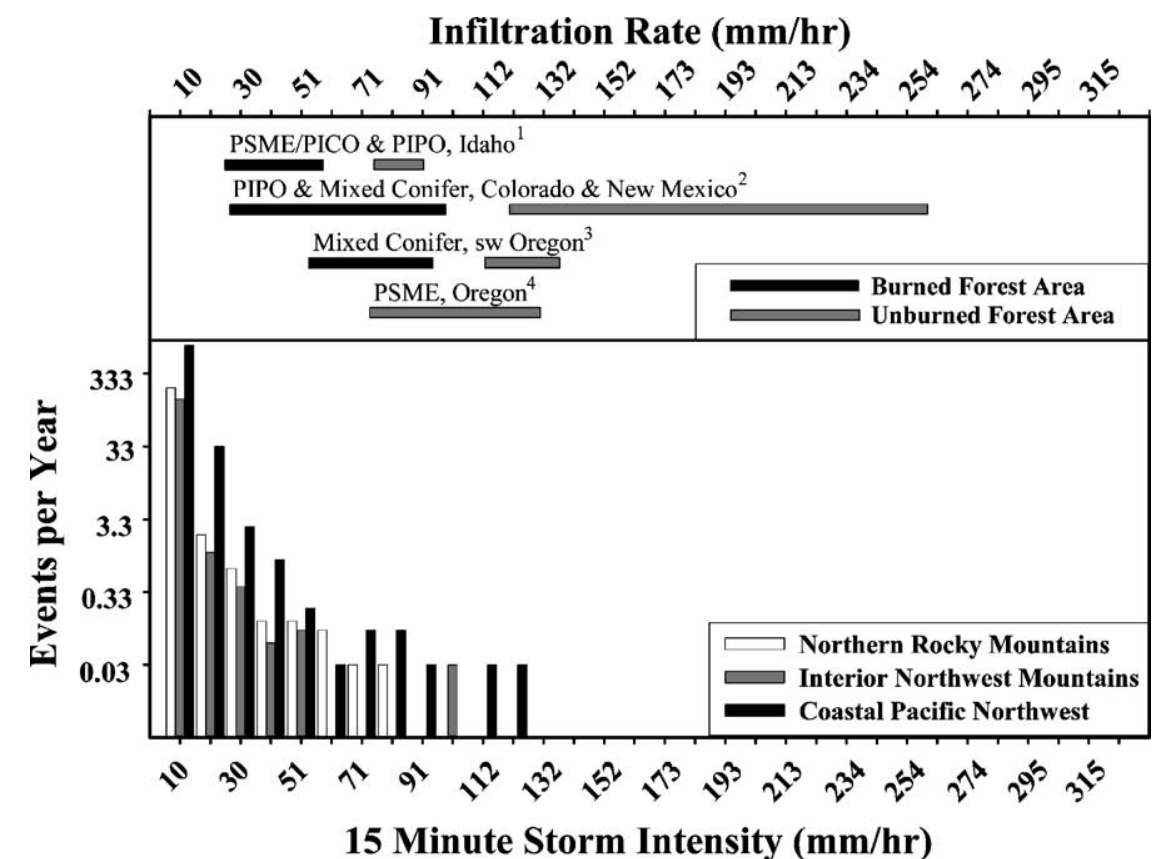

Fig. 1. Soil-infiltration rates in burned- and unburned-forest areas (top panel) and rainfall intensity (bottom panel). Infiltration data is from (1) Robichaud (2000), (2) Moody and Martin (2001a), (3) McNabb et al. (1989), and (4) Johnson and Beschta (1981). Abbreviations denote dominant tree species in the forests at each study site. PSME: Pseudotsuga menzesii (Douglas fir); PICO: Pinus contortus (lodgepole pine); PIPO: Pinus ponderosa (ponderosa pine). Rainfall data from NOAA 15 min precipitation records for the Quinault Ranger Station, WA (Coastal Pacific Northwest); Ukiah, OR (Interior Pacific Northwest); and McCall, ID (Northern Rocky Mountains).

the Pacific Northwest Region than in thunderstormdominated continental climate of the Interior Region. Further, while measured infiltration rates are highly variable, there is no evidence to suggest that infiltration rates are inherently higher in soils of the Pacific Northwest Region than in the Interior Region, nor that postfire changes in infiltration rates are notably different among the regions (Fig. 1). These data raise interesting questions as to why infiltration-excess overland flow and attendant erosion have not been documented in the Coastal and Cascade Mountains of the Pacific Northwest.

Rapid recovery of fire-caused reductions in infiltration rates, high antecedent soil moisture, and rapid rates of vegetative regrowth after fires might all explain why postfire, infiltration-excess, overland flow has not been reported in the Pacific Northwest Region. The soils of many unburned forested areas are hydrophobic when dry (Benavides-Solorio and MacDonald, 2001; Huffman et al., 2001); however, hydrophobicity is not evident in these soils once moisture content exceeds
12-25\% (Huffman et al., 2001). Hydrophobicity tends to increase following fire. Fire-caused hydrophobic layers can persist in the soils of some forest types for long periods. For example, hydrophobic layers in the soils of dry pine forests can persist for months to years (Dyrness, 1976; Huffman et al., 2001), and after intense wildfires, reduced infiltration rates can persist for as long as 6 years (Dyrness, 1976). In contrast, McNabb et al. (1989) showed rapid loss of hydrophobicity and rapid recovery of infiltration rates after prescribed fires in Coastal Mountains of southern Oregon.

In the Interior Region, where summer rainfall is from thunderstorms, it is likely that intense rain will fall on dry soils. In the Pacific Northwest Region, in contrast, intense rain is much more likely to fall on wet soils. Furthermore, thunderstorms occur on 20-30 days during the summer in the Interior Region, and thunderstorms occur less than 5 days per year in Pacific Northwest Region (Miller et al., 1963). In addition, the rainy season is long in the Coastal and western Cascade Mountains, driven by frequent frontal 
storms off the northern Pacific. These storms do bring intense rainfall to the Pacific Northwest, but these usually occur as an intense storm cell imbedded in the larger, frontal storm.

The prevalence of low-intensity rainfall, relatively high soil moisture, and rapid recovery of groundcovering vegetation after fires might all restrict the window of time after burning during which soils are at risk of accelerated erosion from infiltrationexcess overland flow in maritime climate-dominated areas of the Pacific Northwest Region. These factors could substantially reduce the probability that surface erosion will occur, and given the relative rarity of severe fires in the Coastal and Cascade mountains in recent decades, perhaps it is not surprising that infiltration-excess overland flow and wide-scale surface erosion have not been documented within the region.

\subsection{Mass wasting}

Mass wasting is most common in the steep topography of mountainous areas, but can occur anywhere geomorphic processes create steeply sloping landforms, including steep valley-side slopes or cut banks above active river channels. Geologists and geomorphologists recognize many unique classes of mass-wasting events and have developed a systematic classification scheme and naming conventions for mass-wasting processes (see Varnes, 1978), however, the physical basis for distinguishing among types of mass-wasting and erosional transport events is complex. Many mass-wasting events include several uniquely defined processes linked in a sequence along a stream network that Nakamura et al. (2000) called a disturbance cascade. For example, debris slides commonly create debris flows that form debris jams. If debris jams impound water and subsequently burst, they can release flood surges. Further, flow properties of sediment in transport may change substantially within a single event, ranging across the continuum from debris flows, to hyperconcentrated flows, to sediment-laden water floods (Costa, 1988; Grant Meyer, personal communication). Although consideration of all possible mass wasting and erosional transport processes is beyond the scope of this paper, it is important to recognize that different types of processes may have different effects on stream channel morphology, and thus have variable influence on the habitat of fish and other aquatic organisms. For this paper, however, we focus on a few basic types of mass-wasting processes, namely, ravel, debris slides, and debris flows. Further, we follow Nakamura et al. (2000), and generically refer to the shallow sliding of rock, sediment, and soil on hillslopes as debris slides. Debris slides can reach stream channels, and the downchannel flow of that rock, sediment, and soil we call debris flows.

Severe fires clearly increase the frequency and magnitude of a variety of episodic mass-wasting events. Postfire debris slides and debris flows are the most frequently studied postfire mass-wasting processes. Other mass-wasting processes affected by fire include soil creep and deep-seated earth flows (Swanson, 1981), both of which are set in motion by soil saturation. Loss of forest canopies decreases evapotranspiration and can result in more frequent or longer periods of soil saturation. Although the physical cause-effect relationship is clear, we do not know of any studies providing empirical evidence to confirm that view. However, forest removal by logging has resulted in wetter soil conditions and generally higher creep rates (Gray, 1977). Increased peak flows may also occur following severe wildfire (Helvey, 1973; Cheng, 1980; Elliott and Parker, 2001; Moody and Martin, 2001b), which in turn can cause bank erosion and bank-side slides that increase delivery of wood and sediment to channels.

\subsection{Ravel}

Ravel (often called dry ravel) is the rapid downhill movement of individual particles and can include both organic and inorganic materials of various sizes (Swanson, 1981). Ravel occurs preferentially on steep to very steep slopes. Mersereau and Dyrness (1972) found four times more ravel from $80 \%$ slopes than from $60 \%$ slopes. Also, ravel is much greater in noncohesive soils. Many soils lose cohesiveness on drying, so that ravel preferentially occurs during the dry season, and from exposed, south-facing hillslopes. Vegetation tends to stabilize the soil surface, so that little ravel occurs, even on steep south-facing slopes, if vegetation cover exceeds 50-75\% (Mersereau and Dyrness, 1972).

Ravel is unique, in that it is the only mass-wasting process accelerated by wildfire that occurs 
independently of postfire storm events. Severe fire removes litter, duff and vegetation that stabilize the soil; heating combusts soil organic matter that binds soil aggregates and dries the soil decreasing soil cohesion; and fire consumes logs and other organic barriers that store sediment thereby making more sediment available to be moved by ravel. Fire effects on ravel may be short lived. One study from the Oregon Coast Range found that ravel occurring in the first $24 \mathrm{~h}$ after burning accounted for approximately two-thirds of the total ravel measured in the first year after burning (Bennett, 1982). Another study in the western Cascade Mountains showed that rates of ravel were reduced to near zero by the second growing season after prescribed burning which was attributed to rapid recovery of vegetation (Mersereau and Dyrness, 1972). Accelerated rates of ravel might be expected to persist much longer wherever postfire vegetation recovery is slow, for example, in low-elevation, dry forest types growing on south-facing slopes in the Interior Region, especially on noncohesive soils derived from granitic parent materials. Megahan et al. (1995) showed that accelerated erosion rates persisted for at least 10 years on south-facing slopes following helicopter logging and prescribed burning, probably because low water availability limited the rate of vegetative recovery after burning. In contrast, near complete recovery of accelerated sediment yields was observed on north-facing slopes by 3 years after burning. However, these were watershed-scale studies (Megahan et al., 1995), so the relative contribution of ravel and surface erosion to the sediment budgets cannot be differentiated. Ravel can be substantial after severe fires and can contribute to sediment loading of channels adjacent to steep slopes, but in many cases, raveled sediment will only be transported short distances before being captured in storage locations.

\subsection{Debris flows}

Debris flows can be initiated in two ways-either from surface runoff or from debris slides. Because overland flow seldom occurs in the Pacific Northwest Region, runoff-initiated debris flows have not yet been documented within the region. In contrast, both types of initiation events have been documented for debris flows in the Interior Region, and elsewhere throughout western North America. Numerous studies have docu- mented increased frequency of debris flows following severe wildfire.

\subsubsection{Runoff-initiated debris flows}

Debris flows can be initiated by overland flows of water, although there is some debate as to the exact mechanism through which such debris flows are generated. Meyer and Wells (1997) and Cannon et al. (2001) suggest that runoff-initiated debris flows occur when surface runoff entrains fine sediment over large areas and converges to begin carving small rills and larger gullies, eventually entraining sufficient sediment to form debris flows on hillslopes or high in the channel network. In other cases, sediment-laden water floods in steep headwater channels must entrain additional sediment from channel and bank erosion to transition to debris flows (Meyer and Wells, 1997). These events are often referred to as bulking flows. Alternatively, Wells (1987) and DeBano (2000) suggested that tiny debris slides from saturated soils above hydrophobic layers a few centimeters deep create debris flows, which in turn carve the network of rills and small gullies commonly observed in the initiation zone of these events. However, neither Meyer and Wells (1997) nor Cannon et al. (2001) have seen evidence of tiny debris slides at their study sites. Regardless the specific sequence of events that initiates these debris flows, it is clear that they are not caused by en-masse release of sediment from large debris slides.

Runoff-initiated debris flows are relatively common, and have been observed in a variety of environments including the northern Rockies (Meyer and Wells, 1997), the southern Rocky Mountains (Cannon et al., 2001), the interior Northwest (William Russell, Oregon State University, personal communication), and California (Wells, 1987), but not in the Coastal or western Cascade mountains of the Pacific Northwest. Because these debris flows result from surface runoff, they are ultimately controlled by the same suite of factors that control surface erosion, namely rainfall intensity and soil-infiltration rates. Also, they respond similarly to fire-induced changes in infiltration rates, with one important additional factor. Both Meyer and Wells (1997) and Cannon et al. (2001) suggest that the abundance of fine sediment and ash on the surface of recently burned soils is critical to generating debrisflow conditions. 


\subsubsection{Debris slides and debris slide-initiated debris flows}

Debris slides occur when a large mass of sediment, often 100s of cubic meters in size, moves en masse on steep hillslopes. Debris slides tend to be associated with major storm events and floods (Megahan et al., 1978; Rapp et al., 1991; McClelland et al., 1997). In many cases, major storm systems are large enough to cause widespread impact from debris slides and debris flows over large regions. For example, numerous slides and debris flows were recorded from the Pacific coast to central and northern Idaho during the winter of 1996, a year marked by 50 - to 100 -year return interval floods (McClelland et al., 1997; Hofmeister, 2000; Nakamura et al., 2000; Meyer et al., 2001). Of course debris slides and debris flows occur during smaller magnitude storms, but in these cases, debris slides are relatively less frequent and are not as widespread.

Swanston (1971) applied soil mechanic theory to describe debris slide initiation. This theory predicts that debris slides occur if shear stresses equal or exceed shear strength (the combined resistance to movement provided by friction against the shear plane and internal cohesion of the soil). The balance between shear stress and shear strength is primarily a result of slope steepness and both the type and thickness of sediment. However, shear stresses and shear strength are also influenced by a variety of external processes. These include increased loading of the soil mass through increases in water content during storms, or from sediment deposition caused by ravel, soil creep, earth flow, or surface erosion; the loss of physical support, for example by bank erosion undercutting steep slopes above a river channel; decreased frictional resistance caused by increased pore-water pressure when soils become saturated; and finally, decreases in internal cohesion caused by changes in soil-moisture content and loss of mechanical cohesion provided by roots (Swanston, 1971; Swanson, 1981).

Fire indirectly influences the balance between shear stresses and shear strength. For example, fire accelerates rates of ravel and surface erosion, depositing sediment in hillslope hollows, a common initiation point for debris slides (Dietrich et al., 1982). Fire can also lead to increased peak flows and may therefore contribute to accelerated bank erosion with a concurrent increase in rates of bank-side sliding. However, increased soil-water content and decreased root strength are the most important factors leading to accelerated rates of debris sliding after fire (Swanston, 1971; Swanson, 1981).

The close association of debris slides with extreme storm events results from the relationship between pore-water pressures and the rate at which water is added to the soil (Swanston, 1971). Thus, discounting other factors, the relative likelihood of debris slide occurrence should be highly correlated with the probability of occurrence of extreme storms. Regional trends in 50-year return-frequency storms show that $24 \mathrm{~h}$ precipitation totals range from $17 \mathrm{~cm}$ to more than $25 \mathrm{~cm}$ in the Pacific Northwest Region, but decrease to only $7-13 \mathrm{~cm}$ east of the crest of the Cascades in the Interior Region (NOAA, 1973). These storm effects on debris slide occurrence are further accentuated by rain-on-snow events that can greatly increase the amount of water flowing into the soil. Winter temperatures tend to be mild west of the crest of the Cascade Mountains, creating a transitional snow zone. Snow levels may drop to $500 \mathrm{~m}$ in elevation, or less during particularly cold frontal storms. Warmer storms may bring rainfall to $1200 \mathrm{~m}$ in elevation, or even much higher. Thus, between elevations of approximately 500-1000 m, deep snow can accumulate, but the snow pack tends to be warm and very wet. These ripe snow packs melt rapidly during major warm storms, dramatically increasing the amounts of water reaching the soil. In contrast, the snow pack tends to be colder and drier in the more continental climatic regime of the Interior Region. Therefore, it takes longer for the snow pack to begin to melt and release water to the underlying soil when warm Pacific frontal systems bring rain to the mountains of the interior during the winter. Thus, rain-on-snow events should be relatively less common in the interior. When they do occur, however, they are often associated with widespread occurrence of debris slides (Megahan et al., 1978). The Interior Region is characterized by snowmelt-dominated hydrologic systems. Years in which the spring season is long and cool lead to slow melting of the snow pack so that few debris slides occur. However, a rapid shift to hot weather in the spring can lead to rapid melting of the snow pack and trigger debris slides (Megahan et al., 1978; Helvey, 1980). Spring snowmelt has not been identified as an important mechanism triggering debris slides in the Pacific Northwest Region. 
Storm effects on debris slides are greatly affected by loss of the forest canopy caused either by standreplacing wildfire or clearcut harvesting. First, evapotranspiration is decreased so that soils remain wetter over longer periods (Swanston, 1971; Klock and Helvey, 1976; Helvey, 1980; Swanson, 1981; McNabb and Swanson, 1990). Consequently, the threshold of storm magnitude needed to bring the soil to saturation and trigger debris slides can be reduced after severe wildfire. Loss of the forest canopy also accentuates the effect of rain-on-snow events. Energy budgets of snowmelt during rain-on-snow events shows that the relatively "warm" rain provides little energy to melt snow. Rather, the primary source of energy to melt snow is the condensation of water vapor onto the snow pack (Berris and Harr, 1987; Harr, 1981; Swanson, 1981; McNabb and Swanson, 1990). Dense forest canopies shelter the snow surface from strong winds. After a stand replacing fire, however, wind reaches the surface of the snow pack where vapor from the warm, humid air condenses directly onto the snow pack so that prolonged storm events can melt substantial amounts of snow.

Decreases in internal cohesion caused by loss of mechanical cohesion as roots of fire-killed trees decompose can also decrease the effective soil strength, making slopes more susceptible to debris sliding (Swanston, 1971; Swanson, 1981; McNabb and Swanson, 1990). Several studies show an apparent increase in debris slide occurrence 5-10 years after severe wildfire or clearcut harvesting, and suggest this pattern would be consistent with temporal trends in loss of mechanical cohesion from decomposing roots (Megahan et al., 1978).

The movement and transport of sediment from debris slides may follow one of the several different trajectories (Nakamura et al., 2000). The initial failure and movement of sediment may occur as a block of soil and sediment that remains relatively intact, and moves only a short distance before coming to rest. Alternatively, initial failure and movement may lead to rapid disaggregation of the slide mass and formation of a debris slide. On concave slopes, debris slides may be deposited on lower angled hillslopes below the initiation point. Alternatively, the debris slide may continue down slope, eventually reaching the channel network (Nakamura et al., 2000).

Once debris slides reach the channel network, they can be deposited as debris jams or can be mobilized into debris flows. Debris flows may stall in lowergradient stream reaches or at tributary junctions with larger streams, especially if the channel junction occurs at oblique angles, or if the tributary crosses a large, low angled alluvial fan or a wide floodplain developed in the mainstem valley floor (Nakamura et al., 2000). Alternatively, debris flows may continue long distances down relatively large streams (Wondzell and Swanson, 1999). Wherever debris flows finally stop, they typically construct large jams of sediment and wood which often block the stream channel and create zones of sediment deposition immediately upstream (Montgomery et al., 1996; Wondzell and Swanson, 1999; Benda, this issue). During major floods, debris jams can impound water, and in some cases, may fail catastrophically releasing flood surges downstream (Nakamura et al., 2000).

\subsubsection{Contrasting runoff-initiated versus debris-slide-initiated debris flows}

In areas where both runoff-initiated and debrisslide-initiated debris flows occur, it is difficult to assess the relative importance of the different initiation sequences in sediment budgets. The difference in occurrence should depend on the relative probability of debris slides and the relative frequency of overlandflow generation. However, even in areas with known high debris slide hazard, there is great variation among geologic parent materials and among landforms in the relative susceptibility of slopes to debris sliding, regardless of the degree of disturbance (Swanson and Dyrness, 1975; McClelland et al., 1999). Similarly, the likelihood of surface runoff is dependent on climatic, soil and vegetation factors, and both soil properties and vegetation change with time following fire. Consequently, great local and regional variation should be expected in the relative frequencies of the two debris-flow initiation mechanisms.

Meyer et al. (2001) suggested a general hypothesis to explain differences in the timing of runoff-initiated and debris-slide-initiated debris flows. They suggested that runoff-initiated debris flows tend to occur within 1 or 2 years after a severe fire while debris-slideinitiated debris flows will tend to occur some 5-10 years after a fire. In most places, fire-induced water repellency is short lived because hydrophobic compounds break down in a few years. Similarly, stripping of fines from the soil surface in previous erosional 
events, and both compaction and increased cohesion of the surface soil layer reduce the influence of fine sediment and ash on infiltration rates. Additionally, recovery of ground-cover vegetation rapidly stabilizes the soil surface. All these processes reduce the likelihood of overland flow and surface erosion and also reduce the availability of fine sediment needed to generate debris flows (Meyer and Wells, 1997). During this same period, however, roots from fire-killed trees are decomposing, and while tree seedlings may be reestablishing in the burned areas, it will be many years before they regrow extensive root networks. Thus, mechanical cohesion should reach a minimum between 5 and 10 years after wildfire. In both cases, however, extreme climatic events are needed to trigger these debris flows. The high variability in the timing of extreme climatic events often prevents such clearcut sequences in the timing of episodic erosional events.

\section{Discussion}

Erosional processes following wildfire are distinctly different between the forested landscapes of the Interior and Pacific Northwest regions. Because erosion is controlled by a variety of factors relating to soils, geology, topography, vegetation and climate, variability in erosional processes within a region may be as large as variability between regions. However, in reviewing the available literature several major differences in erosional processes are apparent between these two regions.

Surface erosion from infiltration-excess overland flow is a dominant response after wildfire in the Interior Region, but has not been documented in the Pacific Northwest Region. The likelihood of surface erosion from overland flow is a function of the probability of intense storm occurrence and the surface soil conditions regulating infiltration. Measured postfire infiltration rates and precipitation intensities (Fig. 1) suggest that surface runoff from infiltration-excess overland flow could occur in the Coastal and Cascade Mountains of the Pacific Northwest after fires. We hypothesize that the frequency of high intensity convective storms during the summer in the Interior Region increases the probability of rainfall on dry soils and, when combined with generally less rapid vegetation recovery, substantially increases the likelihood of overland flow and surface erosion following fire.
In both the Pacific Northwest Region and the Interior Region, increases in debris slides and debris-slideinitiated debris flows can occur following wildfire because of increased soil-water content and decreased root strength. Debris slides and related debris flows are more probable in the Pacific Northwest Region due to greater annual precipitation, larger storms (e.g. $24 \mathrm{~h}$ precipitation totals for 50-year return-frequency events) and more widespread occurrence of rain-on-snow events. In addition, the reduction in evapotranspiration and the resulting increase in soil water following vegetation removal generally tend to be larger for regions with larger annual precipitation. Also, forest removal in the rain-on-snow zone in much of the Pacific Northwest Region may cause increases in latent heat inputs to the snowpack during rain events such that water input rates to the soils are greatly enhanced. Loss of shear strength of the soil over time after a severe fire, as tree roots decay, typically results in increases in debris slide occurrence 5-10 years postfire.

In the Interior Region, increases in runoff-initiated debris flows can also occur following wildfire; however, these have not been observed in the Pacific Northwest Region. In the Interior Region, the mechanisms that generate overland flow can lead to debris flows if discharge and available sediment are sufficient. Thus, the abundance of fine sediment and ash on the soil surface of recently burned areas may be critical in generating debris flows (Meyer and Wells, 1997; Cannon et al., 2001). The likelihood of runoff-initiated debris flows is a function of the probability of intense storm occurrence, the surface soil conditions regulating infiltration, and the abundance of surface fines.

In the Interior Region the time frame of susceptibility to accelerated erosion following fire is considerably longer than in the Pacific Northwest Region. Immediately following the fire and for some time period thereafter, sites are susceptible to overland runoff and related surface erosion and debris flow occurrence. Areas are also susceptible to debris slide and related debris flow activity about 5-10 years following fire. This latter window of susceptibility appears to be the primary time frame for accelerated fire-related erosion in the Pacific Northwest Region.

Our review of the literature suggests that severe wildland fires affect hillslope erosion and stream sedimentation in forested watersheds. However, this conclusion probably presents an unbalanced assessment of 
the overall effect of fire on erosion and sedimentation rates. Most of the studies in the literature, and therefore most of the studies cited in this review, examine the effects of either (1) severe wildfire followed by large to extreme storms that generate episodic erosion, or (2) clearcut harvesting followed by "prescribed" burning of residual logging slash (especially for studies of fire effects in the Pacific Northwest Region). Consequently, we know little about effects of moderate to low severity wildfire on erosion. Also, the effects of other landuse practices, especially logging and road building, confound our knowledge about the effects of fire. Clearly, more research is needed to better understand the effects of moderate to low severity fires, including prescribed fires, on erosional processes in forested watersheds.

Our knowledge of the role of massive, episodic inputs of sediment to streams is poor. Firstly, because they are episodic, it is difficult to make good estimates of the relative contribution of episodic inputs to sediment budgets. Erosion rates have been measured in a variety of studies, from small-plot studies under either ambient climate or artificial precipitation, to small watershed sediment budgets, to the use of radionuclide tracers (cesium-137) deposited in the 1950s and 1960s (Coppinger et al., 1991) from testing of nuclear bombs, to the use of cosmogenic isotopes. Different types of studies provide estimates of erosion rates integrated over different time periods-from single storms in some plot-scale studies to thousands of years in cosmogenic isotope studies-and consequently result in different estimates of erosion rates. Erosion estimates derived from short-term, small-watershed studies often considerably underestimate long-term rates of erosion because these studies typically miss the infrequent but large, episodic events such as debris slides and debris flows (Kirchner et al., 2001). Alternatively, extending erosion rates measured in smallplot studies to watersheds or regions may overestimate erosion rates because much sediment eroded from hillslopes is only transported a short distance before being redeposited. Sediment eroded from hillslopes may also be deposited on alluvial fans or floodplains where it can be stored for hundreds to thousands of years (Meyer et al., 1995; Clayton and Megahan, 1997; Trimble and Crosson, 2000; Moody and Martin, 2001a). These problems make it difficult to estimate erosion rates and determine how they will change in response to a specific disturbance such as fire. More research is needed to understand better the links and feedbacks between fire, surface erosion, and episodic mass-wasting events.

The effectiveness of different types of erosional, mass-wasting, and sediment transport events in shaping stream channels should be expected to differ, and therefore should influence ecological functions in stream ecosystems in different ways. For example, the relative proportion of water and sediment, and the abundance of fine sediment determine the flow properties of eroded materials while in transport (Costa, 1988). Fluid-like flows of sediment-laden water floods do not generate high shear stresses (Costa, 1988), and as a consequence, they should have relatively less impact on channel morphology than do debris flows. Debris flows are much less fluid, moving as a viscoplastic mass (Costa, 1988) that can dramatically reshape channel morphology (Wondzell and Swanson, 1999; Benda, this issue). Also, debris flows are more competent to transport large boulders and logs and deposit them in stream channels, thus adding physical structure to stream channels. The morphology of channels shaped by debris flows, combined with the coarse sediments and wood delivered to stream channels may be important for maintaining long-term habitat diversity and suitable spawning gravels in some stream systems (Swanston, 1991; Reeves et al., 1995). In contrast, surface erosion from sheet flow or rill networks are more likely to deliver only finetextured sediment and fine-particulate organic matter to streams. The input of fine sediment and its subsequent movement downstream will have different effects on aquatic habitat than will large particles delivered by debris flows. The links between some erosional and mass-wasting processes and channel morphology are well studied. The links between some channel morphologic features and a variety of ecosystem, community, and population responses in aquatic ecosystems are also well studied. However, we still know relatively little about how different types of erosional and masswasting events will influence stream ecosystem processes and the stream habitats required by aquatic species.

\section{Acknowledgements}

We thank Tom Badger, Pete Bisson, Wendy Gerstel, Charlie Luce, Grant Meyer, and Will Russell for 
discussions that improved this manuscript. We also thank two anonymous reviewers for helpful comments.

\section{References}

Benavides-Solorio, J., MacDonald, L.H., 2001. Post-fire runoff and erosion from simulated rainfall on small plots, Colorado Front Range. Hydrol. Process. 15, 2931-2952.

Benda, L.E., this issue. The role of fire and punctuated sediment and wood supplies on channel and valley morphologies and aquatic habitats. For. Ecol. Manage.

Bennett, K.A., 1982. Effects of slash burning on surface erosion rates in the Oregon Coast Range. M.S. Thesis, Oregon State University, Corvallis.

Berris, S.N., Harr, R.D., 1987. Comparative snow accumulation and melt during rainfall in forested and clear-cut plots in the western Cascades of Oregon. Water Resour. Res. 23, 135-142.

Beschta, R.L., 1990. Effects of fire on water quantity and quality. In: Walsad, J.D., Radosevich, S.R., Sandberg, D.V. (Eds.), Natural and Prescribed Fire in the Pacific Northwest Forests. Oregon State University Press, Corvallis, OR, pp. 219-231.

Cannon, S.H., Bigio, E.R., Mine, E., 2001. A process for firerelated debris flow initiation, Cerro Grande fire, New Mexico. Hydrol. Process. 15, 3011-3023.

Cheng, J.D., 1980. Hydrologic effects of a severe forest fire. In: Proceedings of the Symposium on Watershed Management. American Society of Civil Engineers, New York, pp. 240-251.

Clayton, J.L., Megahan, W.F., 1997. Natural erosion rates and their prediction in the Idaho batholith. J. Am. Water Resour. Assoc. 33, 689-703.

Coppinger, K.D., Reiners, W.A., Burke, I.C., Olson, R.K., 1991. Net erosion on a sagebrush steppe landscape as determined by Cesium-137 distribution. Soil Sci. Soc. Am. J. 55, 254-258.

Costa, J.E., 1988. Rheologic, geomorphoic, and sedimentologic differentiation of water floods, hyperconcentrated flows, and debris flows. In: Baker, V.R., Kochel, R.C., Patton, P.C. (Eds.), Flood Geomorphology. Wiley, New York, pp. $113-122$.

DeBano, L.F., 2000. The role of fire and soil heating on water repellency in wildland environments: a review. J. Hydrol. 231232, 195-206.

DeBano, L.F., Neary, D.G., Ffolliott, P.F., 1998. Physical soil system. In: DeBano, L.F., Neary, D.G., Ffolliott, P.F. (Eds.), Fire's Effects on Ecosystems. Wiley, New York, pp. 84-102.

Dietrich, W.E., Dunne, T., Humphrey, N., Reid, L.M., 1982. Construction of sediment budgets for drainage basins. In: Swanson, F.J., Janda, R.J., Dunne, T., Swanston, D.N. (Eds.), Sediment Budgets and Routing in Forested Drainage Basins. General Technical Report PNW-141. USDA Forest Service, Pacific Northwest Forest and Range Experiment Station, Portland, OR, pp. 5-23.

Dyrness, C.T., 1976. Effect of wildfire on soil wettability in the high Cascades of Oregon. Research Paper, PNW-202. USDA Forest Service, Pacific Northwest Forest and Range Experiment Station, Portland OR.
Elliott, J.G., Parker, R.S., 2001. Developing a post-fire flood chronology and recurrence probability from alluvial stratigraphy in the Buffalo Creek watershed, Colorado, USA. Hydrol. Process. 15, 3039-3051.

Gray, D.H., 1977. Creep movement and soil moisture stress in forested vs. cutover slopes: results of field studies (final report). National Science Foundation, Grant No. ENG 74-02427, $141 \mathrm{pp}$.

Gresswell, R.E., 1999. Fire and aquatic ecosystems in forested biomes of North America. Trans. Am. Fish. Soc. 128, 193-221.

Harr, R.D., 1979. Effects of timber harvesting on streamflow in the rain-dominated portion of the Pacific Northwest. In: Proceedings of the Workshop on Scheduling Timber Harvest for Hydrologic Concerns. USDA Forest Service, Pacific Northwest Forest and Range Experiment Station, Portland, OR, pp. 2-45.

Harr, R.D., 1981. Some characteristics and consequences of snowmelt during rainfall in western Oregon. J. Hydrol. 53, 277-304.

Helvey, J.D., 1973. Watershed behavior after forest fire in Washington. In: Proceedings of the Irrigation and Drainage Division Specialty Conference. American Society of Civil Engineers, Fort Collins, CO, April 22-24, 1973, pp. 403-422.

Helvey, J.D., 1980. Effects of a north-central Washington wildfire on runoff and sediment production. Water Resour. Bull. 16, 627-634.

Hofmeister, R.J., 2000. Slope failures in Oregon: GIS inventory for three 1996/97 storm events. Special Paper 34, Oregon Department of Geology and Mineral Industries.

Huffman, E.L., MacDonald, L.H., Stednick, J.D., 2001. Strength and persistence of fire-induced soil hydrophobicity under ponderosa and lodgepole pine, Colorado Front Range. Hydrol. Process. 15, 2877-2892.

Johansen, M.P., Hakonson, T.E., Breshears, D.D., 2001. Post-fire runoff and erosion from rainfall simulation: contrasting forests with shrublands and grasslands. Hydrol. Process. 15, 2953-2965.

Johnson, M.G., Beschta, R.L., 1980. Logging, infiltration capacity, and surface erodibility in western Oregon. J. For. 78 (June (6)), 334-337.

Johnson, M.G., Beschta, R.L., 1981. Seasonal variation of infiltration capacities of soils in western Oregon. Res. Note USDA For. Serv. Pac. Northwest For. Range Expt. Stn. PNW-373, Portland, OR.

Kirchner, J.W., Finkel, R.C., Riebe, C.S., Granger, D.E., Clayton, J.L., King, J.G., Megahan, W.F., 2001. Mountain erosion over 10 -year, 10,000-year, and 10,000,000-year timescales. Geology 29, 591-594.

Klock, G.O., Helvey, J.D., 1976. Soil-water trends following wildfire on the Entiat Experimental Forest. In: Proceedings of the Annual Tall Timbers Fire Ecology Conference No. 15. USDA For. Serv. Tall Timbers Res. Stn., Tallahassee, FL, pp. 193-200.

Martin, D.A., Moody, J.A., 2001. Comparison of soil infiltration rates in burned and unburned mountainous watersheds. Hydrol. Process. 15, 2893-2903.

McClelland, D.E., Foltz, R.B., Wilson, W.D., Cundy, T., Heinemann, R., Saurbier, J., Schuster, R.L., 1997. Assessment of the 
1995 \& 1996 floods and landslides on the Clearwater National Forest. Part I. Landslide Assessment. A report to the Regional Forester. USDA For. Serv. Northern Region, Missoula, MT.

McClelland, D.E., Foltz, R.B., Falter, C.M., Wilson, W.D., Cundy, T., Schuster, R.L., Saurbier, J., Rabe, C., Heinemann, R., 1999. Relative effects on a low-volume road system of landslides resulting from episodic storms in nothern Idaho. Transp. Res. Rec. 1652, 235-243.

McNabb, D.H., Swanson, F.J., 1990. Effects of fire on soil erosion. In: Walsad, J.D., Radosevich, S.R., Sandberg, D.V. (Eds.), Natural and Prescribed Fire in the Pacific Northwest Forests. Oregon State University Press, Corvallis, pp. 159-176.

McNabb, D.H., Gaweda, F., Froehlich, H.A., 1989. Infiltration, water repellency, and soil moisture content after broadcast burning a forest site in southwest Oregon. J. Soil Water Conserv. 44, 87-90.

Megahan, W.F., Day, N.F., Bliss, T.M., 1978. Landslide occurrence in the western and central northern Rocky Mountain Physiographic Province in Idaho. In: Youngberg, C.T. (Ed.), Proceedings of the 5th North American Forest Soils Conference, Forest Soils and Land Use. Colorado State University, Ft. Collins, pp. 116-139.

Megahan, W.F., King, J.G., Seyedbagheri, K.A., 1995. Hydrologic and erosional responses of a granitic watershed to helicopter logging and broadcast burning. For. Sci. 41, 777-795.

Mersereau, R.C., Dyrness, C.T., 1972. Accelerated mass wasting after logging and slash burning in western Oregon. J. Soil Water Conserv. 27, 112-114.

Meyer, G.A., Pierce, J.L., this issue. Geomorphic and climatic controls on fire-induced sediment pulses in Yellowstone and central Idaho: a Holocene perspective. For. Ecol. Manage.

Meyer, G.A., Wells, S.G., 1997. Fire-related sedimentation events on alluvial fans, Yellowstone National Park, USA. J. Sediment. Res. 67, 776-791.

Meyer, G.A., Wells, S.G., Jull, A.J.T., 1995. Fire and alluvial chronology in Yellowstone National Park: climatic and intrinsic controls on Holocene geomorphic processes. Geol. Soc. Am. Bull. 107, 1211-1230.

Meyer, G.A., Pierce, J.L., Wood, S.H., Jull, A.J.T., 2001. Fire, storms, and erosional events in the Idaho batholith. Hydrol. Process. 15, 3025-3038.

Miller, D.W., Geraghty, J.J., Collins, R.S., 1963. Water atlas of the United States. Water Information Center Inc., Port Washington, LI, NY.

Miller, D.J., Luce, C.H., Benda, L.E., 2003. Time, space, and episodicity of physical disturbance in streams. For. Ecol. Manage. 178 (1-2), 121-140.

Montgomery, D.R., Abbe, T.B., Buffington, J.M., Peterson, N.P., Schmidt, K.M., Stock, J.D., 1996. Distribution of bedrock and alluvial channels in forested mountain drainage basins. Nature $381,587-589$.

Moody, J.A., 2001. Sediment transport regimes after a wildfire in steep mountainous terrain. In: Proceedings of the Seventh Federal Interagency Sedimentation Conference, Reno, NV, pp. X41-X48.

Moody, J.A., Martin, D.A., 2001a. Initial hydrologic and geomorphic response following a wildfire in the Colorado Front Range. Earth Surf. Process. Landforms 26, 1049-1070.
Moody, J.A., Martin, D.A., 2001b. Post-fire, rainfall intensity-peak discharge relations for three mountainous watersheds in the western USA. Hydrol. Process. 15, 2981-2993.

Nakamura, F., Swanson, F.J., Wondzell, S.M., 2000. Disturbance regimes of stream and riparian systems-a disturbance-cascade perspective. Hydrol. Process. 14, 2849-2860.

NOAA, 1973. Rainfall Frequency Atlas of the United States. US Dept. Commerce, National Oceanographic and Atmospheric Administration, National Weather Service, Office of Hydrology. Atlas 2, vol. IX (http://lwf.ncdc.noaa.gov/oa/documentlibrary/ rainfall.html).

Rapp, A., Li, J., Nyberg, R., 1991. Mudflow disasters in mountainous areas. Ambio 20, 210-218.

Reeves, G.H., Benda, L.E., Burnett, K.M., Bisson, P.A., Sedell, J.R., 1995. A disturbance-based ecosystem approach to maintaining and restoring freshwater habitats of evolutionarily significant units of anadromous salmonids in the Pacific Northwest. Am. Fish Soc. Symp. 17, 334-349.

Robichaud, P.R., 2000. Fire effects on infiltration rates after prescribed fire in Northern Rocky Mountain forests, USA. J. Hydrol. 231-232, 220-229.

Robichaud, P.R., Brown, R.E., 1999. What happened after the smoke cleared: onsite erosion rates after a wildfire in eastern Oregon. In: Proceedings of the Annual Summer Specialty Conference. Track 2: Wildland Hydrology. American Water Resources Association, Henderson, VA, pp. 419-426.

Robichaud, P.R., Hungerford, R.D., 2000. Water repellency by laboratory burning of four northern Rocky Mountain forest soils. J. Hydrol. 231-232, 207-219.

Swanson, F.J., 1981. Fire and geomorphic processes. In: Gen. Tech. Rep. USDA For. Serv. WO-26. Washington, DC, pp. 401-420.

Swanson, F.J., Dyrness, C.T., 1975. Impact of clear-cutting and road construction on soil erosion by landslides in the western Cascade Range, Oregon. Geology 3, 393-396.

Swanston, D.N., 1971. Principal soil movement processes influenced by roadbuilding, logging and fire. In: Proceedings of the Symposium on Forest Land Uses and Stream Environment. Oregon State University, Corvallis, pp. 29-40.

Swanston, D.N., 1991. Natural processes. In: Meehan, W.R. (Ed.), Influences of Forest and Rangeland Management on Salmonid Fishes and their Habitats. Am. Fish. Soc. Special Pub. 19, Bethesda, MD.

Trimble, S.W., Crosson, P., 2000. U.S. soil erosion rates-myths and reality. Science 289, 248-250.

Troendle, C.A., Leaf, C.F., 1980. Hydrology. An approach to water resources evaluation of non-point silivicultural sources, A procedural handbook. US Environmental Protection Agency EPA-600/8-80-012 (Chapter III).

Varnes, D.J., 1978. Slope movement types and processes. In: Schuster, R.L., Krizek, R.J. (Eds.), Landslide Analysis and Control. National Academy of Sciences, Transportation Research Board, Special Report 176, pp. 11-13.

Wells, W.G., 1987. The effects of fire on the generation of debris flows in southern California. In: Costa, J.E., Wieczorek, G.F. (Eds.), Debris Flows/Avalanches: Process, Recognition, and Mitigation, vol. VII. Geological Society of America Review in Engineering Geology, pp. 105-114. 
Wells, C.G., Campbell, R.E., DeBano, L.F., Lewis, C.E., Fredriksen, R.L., Franklin, E.C., Froelich, R.C., Dunn, P.H., 1979. Effects of fire on soil: a state-of-knowledge review. Gen. Tech. Rep. USDA For. Serv. WO-7, Washington, DC.

Wilcox, B.P., Newman, B.D., Brandes, D., Davenport, D.W., Reid, K., 1997. Runoff from a semiarid ponderosa pine hillslope in New Mexico. Water Resour. Res. 33, 2301-2314.

Wohlgemuth, P.M., Hubbert, K.R., Robichaud, P.R., 2001. The effects of log erosion barriers on post-fire hydrologic response and sediment yield in small forested watersheds, southern California. Hydrol. Process. 15, 3053-3066.

Wondzell, S.M., 2001. The influence of forest health and protection treatments on erosion and stream sedimentation in forested watersheds of eastern Oregon and Washington. Northwest Sci. $75,128-140$.

Wondzell, S.M., Swanson, F.J., 1999. Floods, channel change, and the hyporheic zone. Water Resour. Res. 35, 555-567. 